\title{
Pengurangan Dosis Pupuk Anorganik dengan Pemberian Kompos Blotong pada Budi Daya TanamanTebu (Saccharum officinarum L.) Lahan Kering
}

\section{Dose Reduction of Inorganic Fertilizer with Filtermud Compost on the Sugarcane Cultivation (Saccharum officinarum L.) in Dryland}

\author{
Mohd Azree Bin Jaili dan Purwono* \\ Departemen Agronomi dan Hortikultura, Fakultas Pertanian, Institut Pertanian Bogor \\ (Bogor Agricultural University), Jl. Meranti, Kampus IPB Darmaga, Bogor 16680, Indonesia \\ Telp. \& Faks.62-251-8629353 e-mail agronipb@indo.net.id \\ *Penulis untuk korespondensi: puripb@gmail.com
}

Disetujui tanggal 18 Januari 2016 / Published online 25 Januari 2016

\begin{abstract}
This research was conducted to study the dose reduction of inorganic fertilizer added with filtercake compost on sugarcane cultivation in the dryland. This research was held at the Sengon Village, District of Prambanan, Klaten Regency under PT. Madubaru, Yogyakarta in December 2014 until June 2015. This study was randomized by a complete block design group with one factor. The treatment doses of fertilizer used were $P 1$ (filtercake compost without inorganic fertilizer), P2 (filtercake compost $+50 \%$ inorganic fertilizer), P3 (filtercake compost $+75 \%$ inorganic fertilizer), P4 (filtercake compost $+100 \%$ inorganic fertilizer) and P5 (100\% inorganic fertilizer without filtercake compost). The dosage of filtercake compost 5 tons of acres ${ }^{-1}$ and inorganic fertilizer (ZA and Phonska) my $5^{-1}$ respectively. Variables were measured the number of stem/meter segment, stem length, stem diameter, the weight of the cane, leaves area and leaves chlorophyll. Result showed the dosage of $75 \%$ inorganic fertilizer without filtercake compost is not different to $100 \%$ inorganic fertilizer with filtercake compost significantly.
\end{abstract}

Keywords: dosage, dryland, filtermud, inorganic, sugarcane

\section{ABSTRAK}

Penelitian ini dilakukan untuk mempelajari pengurangan dosis pupuk anorganik dengan pemberian kompos blotong pada budidaya tanaman tebu lahan kering. Penelitian ini dilaksanakan di Desa Sengon, Kecamatan Prambanan, Kabupaten Klaten di bawah PT. Madubaru, Yogyakarta pada bulan Desember 2014 hingga Juni 2015. Penelitian ini menggunakan rancangan kelompok lengkap teracak satu faktor. Dosis pemupukan yang digunakan adalah P1 (kompos blotong tanpa pupuk anorganik), P2 (kompos blotong $+50 \%$ pupuk anorganik), P3 (kompos blotong $+75 \%$ pupuk anorganik), P4 (kompos blotong $+100 \%$ pupuk anorganik) dan P5 (100\% pupuk anorganik tanpa kompos blotong). Dosis pemberian kompos blotong adalah 5 ton ha ${ }^{-1}$ dan pupuk anorganik (ZA dan Phonska) masing-masing adalah 5 kuintal (ku) ha-l. Peubah yang diamati adalah jumlah batang per meter juring, panjang batang, diameter batang, bobot tebu, luas daun, klorofil daun dan produktivitas tebu. Hasil penelitian menunjukkan dosis pemupukan anorganik $75 \%$ dengan kompos blotong tidak berbeda nyata dengan dosis pemupukan anorganik 100\% tanpa kompos blotong terhadap produktivitas.

Kata kunci: anorganik, dosis, kompos blotong, lahan kering, tebu 


\section{PENDAHULUAN}

Gula kristal putih (GKP) adalah hasil pengolahan tebu yang merupakan salah satu komonitas strategis dalam perekonomian Indonesia. Kebutuhan gula kristal putih dalam negeri selalu meningkat sejalan dengan pertambahan jumlah penduduk dan bertambahnya industri yang menggunakan bahan baku gula, sehingga kebutuhan gula akan semakin meningkat sementara produksi gula nasional masih belum mampu memenuhi hal tersebut. Pada tahun 2014, luas areal lahan tebu seluas 476735 ha dengan produksi gula nasional sebesar 2632424 ton (BPS, 2015). Sementara pada tahun 2015, kebutuhan gula nasional diperkirakan mencapai 5,7 juta ton yang terdiri dari 2,8 juta ton gula kristal putih (GKP) untuk konsumsi langsung masyarakat dan 2,9 juta ton gula kristal rafinasi (GKR) untuk memenuhi kebutuhan industri (Kemenperin, 2015). Hal ini menyebabkan impor gula mentah (raw sugar) semakin meningkat untuk mengimbangi kebutuhan gula dalam negeri.

Permasalahan yang dihadapi industri gula nasional adalah menurunnya produktivitas tebu terutama di Pulau Jawa. Terdapat beberapa faktor yang memicu terjadinya penurunan produktivitas dan kualitas tanaman tebu antara lain terjadinya penggunaan pupuk anorganik secara berlebihan tanpa diimbangi dengan pupuk organik sehingga menyebabkan degradasi kesuburan lahan. Pupuk anorganik adalah zat substansi kandungan hara yang dibutuhkan oleh tumbuhan bertujuan untuk menambah sumber hara yang tersedia di dalam tanah. Penggunaan pupuk anorganik yang terus menerus mengakibatkan tanah berubah secara fisik dan kimia menjadi buruk hingga menurunkan produksi hasil panen tanaman tebu. Selain itu, pupuk anorganik dapat menimbulkan pencemaran lingkungan. Salah satu upaya untuk mengatasi hal ini adalah dengan mengurangi dosis penggunaan pupuk anorganik dan memanfaatkan by product dari gula seperti kompos blotong (Ditjenbun, 2015).

Blotong atau disebut "filtermud" adalah kotoran nira tebu dari proses pembuatan gula yang dapat dimanfaatkan kembali dalam budi daya tanaman tebu. Kotoran nira ini terdiri atas kotoran yang dipisahkan dalam proses penggilingan tebu dan pemurnian gula. Persentase kotoran nira ini cukup tinggi yaitu $9-18 \%$ dari tebu basah, dan sangat cepat terdekomposisi menjadi kompos blotong. Komponen kompos blotong terdiri dari wax dan lemak kasar 5-14 \%, protein kasar 5-15 \%, sabut $15-30 \%$, gula 5-15\%, total abu 9-20\%, $\mathrm{SiO}_{2} 4-10 \%, \mathrm{CaO} 1-4 \%, \mathrm{P}_{2} \mathrm{O}_{5} 1-3 \%$ dan $\mathrm{MgO}$ 5-1.5 \% (Lahuddin, 1996). Pada penelitian ini, produktivitas tebu lahan kering diharapkan dapat ditingkatkan dengan mengurangi dosis pemupukan anorganik dengan memanfaatkan kompos blotong.

\section{BAHAN DAN METODE}

Penelitian ini dilaksanakan di lahan kering Desa Sengon, Kecamatan Prambanan, Kabupaten Klaten, Yogyakarta pada bulan Desember 2014 hingga Juni 2015. Peralatan yang digunakan adalah alat-alat budi daya pertanian umum, plant chlorophyll meter, jangka sorong digital, timbangan digital, gunting, ember, penggaris, meteran, gergaji dan alat tulis. Bahan yang digunakan dalam penelitian ini adalah bibit tebu varietas BL (Bululawang), kompos blotong dan pupuk anorganik (pupuk ZA dan pupuk phonska).

Persiapan lahan dilakukan dengan cara membajak tanah dengan menggunakan traktor. Petak-petak percobaan dibuat dengan ukuran $15 \mathrm{~m}$ $\times 10 \mathrm{~m}$, tiap petak terdiri atas 15 juring dengan panjang juring $10 \mathrm{~m}$ dan jarak antar juring $1 \mathrm{~m}$. Antara petak percobaan dibatasi oleh 1 juring. Bahan tanam yang digunakan adalah benih bagal bermata dua. Jumlah benih 30 stek per juring dengan jarak tanam $10 \mathrm{~cm}$. Sebelum penanaman, benih diseleksi dan disortasi untuk memastikan benih bebas dari varietas campuran dan bersih dari hama dan penyakit sistemik.

Pemberian kompos blotong dilakukan pada saat pengolahan tanah dengan dosis 5 ton ha ${ }^{-1}$. Pemupukan pupuk anorganik diberikan sesuai dosis perlakuan dan pemupukan dilakukan sebanyak dua kali. Jenis pupuk tunggal yang digunakan adalah pupuk ZA yang mengandungi $21 \% \mathrm{~N}$ dengan dosis 5 kuintal $(\mathrm{ku}) \mathrm{ha}^{-1}$. Jenis pupuk majemuk yang digunakan adalah pupuk phonska (15-15-15) dengan dosis 5 kuintal $(\mathrm{ku}) \mathrm{ha}^{-1}$. Pemupukan pertama dilakukan pada saat tanaman berumur 4 minggu setelah tanam (MST) dengan dosis pupuk ZA dan pupuk phonska masing-masing $1 / 2$ dari dosis perlakuan. Pemupukan kedua dilakukan pada saat tanaman berumur 8 MST dengan dosis pupuk ZA dan pupuk phonska masing-masing $1 / 2$ dari dosis perlakuan. Penyulaman adalah kegiatan menanam kembali bibit pada bagian barisan yang kosong karena terjadi kematian rumpun atau bibit yang telah ditanam mati. Penyulaman dilakukan pada saat tanaman berumur 4 MST. Benih yang 
digunakan sebagai bahan sulam adalah benih dederan berumur 4 minggu.

Pembubunan pada tanaman tebu dilakukan tiga kali. Pembumbunan pertama dilakukan pada saat umur tanaman tebu 4 MST untuk merangsang pertumbuhan anakan dan menutup pemupukan I. Pembumbunan dilakukan dengan cara membersihkan rumput-rumputan, membalik guludan dan menghancurkan tanah lalu menambahkan tanah ke tanaman hingga tertimbun tanah. Pembumbunan ke-2 dilakukan jika anakan tebu sudah cukup besar $\pm 20 \mathrm{~cm}$, hingga tidak dikhawatirkan tanaman rusak atau patah sewaktu ditimbun tanah atau tanaman telah berumur 8 MST. Pembumbunan ke-2 bertujuan untuk menambah media perakaran tanaman, menutup pemupukan II dan juga untuk menekan pertumbuhan tumbuhnya anakan tersier dan kuarter. Pembumbunan ke-3 dilakukan pada saat umur tanaman 12 MST agar akar dibagian ruas atas tumbuh, melancarkan aliran air hujan, dan memperkokoh batang tebu agar tidak mudah roboh

Pengamatan parameter pertumbuhan meliputi jumlah batang per meter juring, panjang batang (cm); diukur dari permukaan tanah hingga titik tumbuh, diameter batang $(\mathrm{cm})$; diukur dari nilai tengah batang yang diukur tinggi batangnya, luas daun; diukur pada posisi daun yang berada di bagian tengah, kadar klorofil; diukur pada posisi daun yang berada di bagian tengah dan bobot tanaman diukur dengan jumlah berat tebu per meter tebu. Selain itu juga, pengamatan penunjang dilakukan meliputi analisis kompos blotong dan tanah. Data pengamatan yang diperoleh dianalisis dengan menggunakan analisis ragam (uji $\mathrm{F}$ ) pada taraf $5 \%$. Apabila uji $\mathrm{F}$ nyata maka dilanjutkan dengan uji BNJ pada taraf nyata $5 \%$ untuk mengetahui perbedaan rata-rata antar perlakuan.

\section{HASIL DAN PEMBAHASAN}

\section{Kondisi Umum}

Wilayah Kabupaten Klaten termasuk beriklim tropis basah dengan musim hujan antara bulan Nopember - April dan musim kemarau antara bulan Mei dan Oktober. Curah hujan yang tertinggi pada bulan Januari dengan intensitas $350 \mathrm{~mm}$ dan curah hujan terendah pada bulan Juli $8 \mathrm{~mm}$. Suhu rata-rata per bulan adalah sebesar $28-30^{\circ} \mathrm{C}$ (BPS Klaten, 2014). Kebun ini memiliki luasan $3000 \mathrm{~m}^{2}$ yang hanya mengandalkan hujan sebagai sistem irigasi. Hama yang menyerang tanaman tebu pada saat tebu berumur tiga bulan adalah belalang (Valanga nigricornis $c$.). Hama ini muncul pada musim hujan. Bagian tanaman yang dimakan belalang adalah helai daun dan titik tumbuh. Serangan hama tersebut masih dapat dikawal karena belum mencapai di ambang ekonomis. Pengendalian hama belalang dilakukan dengan dua cara yaitu dengan menggunakan umpan dan penyemprotan kimia. Umpan dibuat dari dedak yang dicampur dengan $0,1 \%$ insektisida. Pengendalian secara kimiawi dilakukan dengan penyemprotan insektisida dengan cara pengabutan.

\section{Pengaruh Pemupukan Anorganik dengan Kompos Blotong Terhadap Tanaman Tebu}

Hasil rekapitulasi sidik ragam perlakuan pemupukan anorganik dengan kompos blotong terhadap karakter pertumbuhan tanaman tebu disajikan pada Tabel 1. Hasil menunjukkan bahwa perlakuan pemupukan anorganik dengan kompos blotong berpengaruh sangat nyata terhadap beberapa karakter tanaman tebu yaitu jumlah batang/meter juring, panjang batang $(\mathrm{m})$, luas daun $(\mathrm{cm})$, klorofil daun (at leaf + ), hasil 6 bulan setelah tanam (ton) dan pendugaan hasil produksi panen (ton). Hal ini berarti pemberian dosis pupuk anorganik yang berbeda dengan kompos blotong mempengaruhi pertumbuhan tanaman tebu. Pemupukan yang seimbang diperlukan agar tanaman mendapat suplai hara yang optimal dan seterusnya mengoptimumkan produksi tebu. Perlakuan pemupukan anorganik dengan kompos blotong tidak berpengaruh nyata terhadap diameter batang $(\mathrm{cm})$ dan bobot tebu $(\mathrm{kg})$. Hasil koefisien keragaman (\%) yang diperoleh menunjukkan karakter yang memiliki nilai koefisien keragaman yang paling rendah adalah jumlah klorofil daun. Karakter yang memiliki nilai koefisien keragaman yang paling tinggi adalah panjang batang $(\mathrm{m})$. Hasil koefisien keragaman yang semakin kecil nilainya menggambarkan hasil penelitian semakin teliti.

Pertumbuhan adalah suatu proses pertambahan volume yang disebabkan oleh pembelahan sel tanaman. Pertumbuhan tanaman tebu terdiri atas fase vegetatif dan fase generatif. Fase vegetatif tebu meliputi perkecambahan, pertunasan dan pertumbuhan batang untuk menentukan biomassa tanaman, sedangkan fase generatif adalah pertumbuhan ke arah fase penimbunan karbohidrat di batang. Dalam penelitian ini, komponen pertumbuhan vegetatif 
tanaman tebu yang diamati adalah batang/meter juring, panjang batang, diameter batang, luas daun, bobot tebu serta jumlah klorofil daun. Komponen ini penting dalam menentukan produksi akhir tanaman tebu yang diperoleh sehingga digunakan sebagai variabel dalam penelitian ini.

Tabel 1. Rekapitulasi sidik ragam perlakuan pemupukan anorganik dengan kompos blotong terhadap karakter tanaman tebu

\begin{tabular}{|c|c|c|}
\hline Peubah & Perlakuan & Koefisien keragaman (\%) \\
\hline Jumlah batang/meter juring & $* *$ & 10.79 \\
\hline Panjang batang (m) & $* *$ & 15.42 \\
\hline Diameter batang (cm) & tn & 8.48 \\
\hline Luas daun $(\mathrm{cm})$ & $* *$ & 10.33 \\
\hline Klorofil daun $($ at leaf + ) & $* *$ & 4.22 \\
\hline Bobot tebu $(\mathrm{kg}) /$ meter & tn & 12.89 \\
\hline Hasil 6 BST (kg) & $* *$ & 10.23 \\
\hline Pendugaan hasil produksi panen(ton) & $* *$ & 10.18 \\
\hline
\end{tabular}

Keterangan : ** berpengaruh nyata pada taraf $5 \%$; tn tidak berpengaruh nyata pada taraf $5 \%$ pada uji $\mathrm{F}$

Luas daun, klorofil daun dan bobot tebu. Berdasarkan analisis ragam terhadap luas daun menunjukkan bahwa perlakuan pemupukan anogranik dengan kompos blotong berbeda nyata tetapi tidak berpengaruh terhadap bobot tebu $\left(\mathrm{kg} \mathrm{m}^{-}\right.$ $\left.{ }^{1}\right)$. Rataan nilai tengah luas daun yang paling tinggi adalah P3 yaitu $808.83 \mathrm{~cm}$. Hal ini menunjukkan bahwa aplikasi dosis pemupukan anorganik $75 \%$ dengan kompos blotong mampu meningkatkan keluasan daun. Penambahan unsur hara dari pupuk anorganik dan kompos blotong dapat memperlebar helaian daun dan munculnya daun baru. Serapan unsur yang meningkat jumlahnya akan menyebabkan luas daun meningkat (Disbun Jabar, 2013). Luas daun berpengaruh pada proses fotosintesis untuk menghasilkan asimilat yang digunakan sebagai sumber energi pertumbuhan dalam membentuk organ vegetatif tanaman. Proses fotosintesis akan terus meningkat sejalan dengan tingginya intesitas sinar matahari. Produk hasil asimilasi menjadi bahan pembangun atau sukrosa akan ditumpuk di batang tebu. Makin besar luas dan makin subur, dan makin besar produksi tebu (tinggi dan diameter batang). Sitompol dan Guritno (1995) dalam penelitiannya menyatakan bahwa tanaman yang mempunyai daun yang lebih luas pada awal pertumbuhan akan lebih cepat tumbuh karena kemampuan menghasilkan fotosintat yang lebih tinggi dari tanaman yang luas daun yang lebih rendah.

Perlakuan pemupukan anorganik dengan kompos blotong juga mempengaruhi secara signifikan terhadap kadar klorofil daun dari hasil analisis sidik ragam. Perlakuan P3 menunjukkan kadar klorofil yang paling tinggi yaitu 61.76 (at leaf
+). Kadar klorofil sangat dipengaruhi oleh kondisi nutrisi tanaman tebu. Hara nitrogen lebih efektif meningkatkan kadar klorofil dibandingkan dengan unsur $\mathrm{P}$ dan $\mathrm{K}$. Defisiensi nitrogen dapat menurunkan kadar klorofil daun tebu. Hal ini sejalan dengan penelitian Sudarijanto dan Mulyatmo (2001) yang menyatakan bahwa pupuk N merupakan salah satu unsur makro esensial yang berperan sebagai bahan pembentuk klorofil, protein dan protoplasma. Tanaman tebu juga memerlukan unsur $\mathrm{K}$ dalam jumlah relatif tinggi yang nantinya sangat berpengaruh terhadap proses fotosintesis dan perpindahan gula baru yang dibentuk di dalam daun ditranslokasikan ke jaringan penyimpanan di batang. Dalam penelitian ini, dosis pemupukan anorganik $75 \%$ dengan kompos blotong merupakan dosis efektif yang dapat meningkatkan kadar klorofil pada daun.

Tabel 2. Rataan nilai tengah pada perlakuan pemupukan anorganik dengan kompos blotong terhadap luas daun $(\mathrm{cm})$, klorofil daun $($ at leaf +$)$ dan bobot tebu $\left(\mathrm{kg} \mathrm{m}^{-1}\right)$ tanaman tebu

\begin{tabular}{lccc}
\hline Perlakuan & $\begin{array}{c}\text { Luas daun } \\
(\mathrm{cm})\end{array}$ & $\begin{array}{c}\text { Klorofil daun } \\
(\text { at leaf }+)\end{array}$ & $\begin{array}{c}\text { Bobot tebu } \\
(\mathrm{kg}) / \mathrm{m}\end{array}$ \\
\hline P1 & $407.45 \mathrm{~b}$ & $44.34 \mathrm{c}$ & 0.39 \\
P2 & $708.01 \mathrm{a}$ & $56.08 \mathrm{~b}$ & 0.50 \\
P3 & $808.83 \mathrm{a}$ & $61.76 \mathrm{a}$ & 0.55 \\
P4 & $803.75 \mathrm{a}$ & $60.13 \mathrm{ab}$ & 0.54 \\
P5 & $754.69 \mathrm{a}$ & $59.04 \mathrm{ab}$ & 0.47 \\
\hline Keterangan: Angka yang diikuti oleh huruf yang berbeda pada \\
\multicolumn{4}{c}{ baris yang sama menunjukkan hasil berbeda nyata } \\
& pada taraf uji 5\%
\end{tabular}


Bobot batang tebu diamati pada hari terakhir penelitian. Pertumbuhan batang tebu merupakan stadium penting yang sangat menentukan besarnya hasil bobot tebu (Disbun Jabar 2013). Berdasarkan hasil penelitian yang diperoleh, P3 memiliki rataan nilai tengah bobot batang tebu yang paling tinggi yaitu $0.55 \mathrm{~kg}$. Menurut Purnomo dan Suriadikarta (2008), nitrogen berkolerasi positif terhadap bobot batang tebu. Hal ini mengindikasikan bahwa nitrogen berperan besar dalam memperbaiki pertumbuhan tebu, bobot batang tebu, dan hablur. Selain unsur N, unsur lain yang tersedia dalam tanah juga dapat dengan mudah diserap tanaman dan ditranslokasikan ke dalam jaringan tebu yang dapat diinterpretasikan sebagai peningkatan bobot batang tebu. Rataan nilai tengah perlakuan pemupukan anorganik dengan kompos blotong terhadap luas daun $(\mathrm{cm})$, klorofil daun $($ at leaf +$)$ dan bobot tebu $\left(\mathrm{kg} \mathrm{m}^{-1}\right)$ dapat dilihat pada Tabel 2 .

Jumlah batang/meter juring, panjang batang dan diameter batang. Perlakuan dosis pemupukan anorganik dengan kompos blotong dapat dilihat pada Tabel 3 berikut ini. Hasil yang diperoleh merupakan rataan nilai tengah. Berdasarkan hasil yang diperoleh, menunjukkan pemupukan P2, P3, P4 dan P5 berpengaruh nyata terhadap karakter jumlah batang /meter juring dan panjang batang (m). Hasil ini sejalan dengan penelitian oleh Mulyadi (2000) yang menyatakan bahwa pemberian blotong nyata meningkatkan jumlah tanaman dalam rumpun, tinggi tanaman dan kadar $\mathrm{N}$ total, $\mathrm{Si}, \mathrm{P}$ dan $\mathrm{S}$ yang tersedia.

Tabel 3. Jumlah batang/meter juring, panjang batang dan diameter batang tanaman tebu

\begin{tabular}{clll}
\hline Perlakuan & $\begin{array}{l}\text { Jumlah } \\
\text { batang/meter } \\
\text { juring }\end{array}$ & $\begin{array}{l}\text { Panjang } \\
\text { batang } \\
(\mathrm{m})\end{array}$ & $\begin{array}{l}\text { Diameter } \\
\text { batang } \\
(\mathrm{cm})\end{array}$ \\
\hline P1 & $5.45 \mathrm{~b}$ & $0.96 \mathrm{~b}$ & 2.27 \\
P2 & $8.43 \mathrm{a}$ & $1.73 \mathrm{a}$ & 2.61 \\
P3 & $10.00 \mathrm{a}$ & $2.10 \mathrm{a}$ & 2.68 \\
P4 & $9.76 \mathrm{a}$ & $2.10 \mathrm{a}$ & 2.67 \\
P5 & $8.73 \mathrm{a}$ & $1.94 \mathrm{a}$ & 2.56 \\
\hline
\end{tabular}

${ }^{a}$ Angka yang diikuti oleh huruf yang berbeda pada baris yang sama menunjukkan hasil berbeda nyata pada taraf uji $5 \%$

Tiap tunas anakan berpotensi untuk menghasilkan jumlah batang optimal. Dari hasil rataan nilai tengah, P3 menunjukkan jumlah batang/meter juring dan panjang batang yang paling banyak. Hal ini membuktikan bahwa dosis pemupukan anorganik $75 \%$ dengan kompos blotong mampu memperbaiki kesuburan tanah dengan meningkatkan ketersediaan unsur $\mathrm{N}$ yang sangat dibutuhkan tanaman pada awal pertumbuhan untuk pembentukan anakan dan pertumbuhan vegetative (Tabel 3).

Menurut Dillewijn (1952) dosis nitrogen yang tinggi akan meningkatkan populasi tanaman tetapi apabila berlebihan akan menyebabkan penurunan kadar gula. Menurut Sudiatso (1999) unsur $\mathrm{N}$ sangat penting dalam penyusunan asam amino, asam nukleat dan klorofil, yang sangat diperlukan untuk pertumbuhan dan perkembangan tanaman. Selain nitrogen, fosfor dalam tanaman juga berperan penting dalam metabolisme, proses pertumbuhan benih, pemasakan batang, perkembangan akar di samping berfungsi sebagai penyangga kemasaman dan kealkalian sel tanaman. Suplai hara yang optimal akan meningkatkan panjang batang tebu sehingga kapasitas simpanan gula juga meningkat. Kombinasi dosis pupuk anorganik $75 \%$ dengan kompos blotong dapat memberikan tambahan unsur hara NPK yang tersedia dalam tanah yang berpengaruh pada tinggi tanaman. Hal ini karena penggunaaan dosis pupuk anorganik $75 \%$ dapat mengurangi kerusakan tanah dan seterusnya kualitas tanah diperbaiki dengan kompos blotong. Dengan adanya penambahan unsur $\mathrm{P}$, maka akan terjadi peningkatan energi dalam bentuk ATP yang dihasilkan untuk fotosintesis sehingga mendukung proses pertumbuhan dan perkembangan tanaman. Hasil ini seiring dengan hasil analisis kimia tanah yang kadar nitrogen pada P3 sangat rendah yaitu $0.06 \%$ yang diduga telah diserap oleh tanaman tebu untuk pertumbuhan anakan dan panjang batang. Sedangkan kadar fosfor pada tanah P3 paling tinggi yaitu $42.90 \mathrm{ppm}$ menunjukkan penambahan pupuk $\mathrm{P}$ telah meningkatkan kadar $\mathrm{P}$ dalam tanah. Akan tetapi unsur $\mathrm{P}$ tergolong tidak mobil sehingga penambahan pupuk yang tidak diserap tanaman akan diikat oleh tanah menjadi bentuk yang tidak tersedia akibat fiksasi.

Dari hasil analisis sidik ragam, pengaruh perlakuan pemupukan anorganik dengan kompos blotong tidak berbeda nyata terhadap diameter. Diameter batang diamati setelah tebu berumur 3 bulan, yaitu pada saat awal pertumbuhan karena tanaman tebu akan mulai menyerap unsur hara pada umur 90 hari atau lebih (Clements, 1980). Menurut Darmodjo (1990) pada waktu tanaman Tebu berumur 3-8 bulan adalah fase pertunasan dan fase pemanjangan batang ketika serapan unsur 
hara berjalan aktif. Akan tetapi P3 memiliki rataan nilai tengah diameter batang tebu yang paling tinggi yaitu $2.68 \mathrm{~cm}$. Hal ini membuktikan bahwa dosis pemupukan anorganik $75 \%$ dengan

Perlakuan dosis pemupukan anorganik dengan kompos blotong terhadap hasil 6 BST $(\mathrm{kg})$ dan pendugaan hasil produksi panen (ton) dapat dilihat pada Tabel 4 berikut ini. Hasil yang diperoleh merupakan rataan nilai tengah.

Tabel 4. Rataan nilai tengah pada perlakuan pemupukan anorganik dengan kompos blotong terhadap hasil 6 BST $(\mathrm{kg})$ dan pendugaan hasil produksi panen (ton) tanaman tebu

\begin{tabular}{ccc}
\hline Perlakuan & $\begin{array}{c}\text { Hasil 6 BST } \\
(\mathrm{kg})\end{array}$ & $\begin{array}{c}\text { Pendugaan hasil } \\
\text { produksi panen (ton) }\end{array}$ \\
\hline P1 & $14632.98 \mathrm{c}$ & $15.16 \mathrm{c}$ \\
P2 & $60869.80 \mathrm{~b}$ & $62.31 \mathrm{~b}$ \\
P3 & $95884.89 \mathrm{a}$ & $97.80 \mathrm{a}$ \\
P4 & $92646.97 \mathrm{a}$ & $94.54 \mathrm{a}$ \\
P5 & $65975.27 \mathrm{~b}$ & $67.48 \mathrm{~b}$ \\
\hline Keterangan: & Angka yang diikuti oleh huruf yang berbeda pada \\
& baris yang sama menunjukkan hasil berbeda nyata \\
& pada taraf uji 5\%
\end{tabular}

Dari hasil analisis ragam, perlakuan pemupukan P3 dengan dosis anorganik $75 \%$ dan kompos blotong $100 \%$ dan perlakuan pemupukan P4 yang mengunakan dosis anorganik 100\% dengan kompos blotong $100 \%$ tidak berbeda nyata terhadap nilai hasil $6 \mathrm{BST}(\mathrm{kg})$ dan pendugaan hasil produksi panen (ton). Perlakuan pemupukan P3 menunjukkan hasil 6 BST $(\mathrm{kg})$ dan pendugaan hasil produksi panen yang tertinggi disbanding perlakuan pemupukan yang lain. Selain dapat meningkatkan produksi tebu, kesuburan tanah juga dapat ditingkatkan pada perlakuan pemupukan P3 berbanding P4 yang dapat dilihat pada Tabel 7 sehingga dapat memicu peningkatan dalam pendugaan hasil produksi panen. Perlakuan P4 mengindikasi terjadinya penggunaan pupuk anorganik yang over dosage sehingga dapat menurunkan kuantitas dan kualitas hara yang tersedia dalam tanah.

\section{Pengaruh Pemupukan Anorganik dengan Kompos Blotong terhadap Sifat Kimia Tanah}

Blotong adalah hasil endapan dari nira kotor yang masih mengandung banyak bahan organik, mineral, serta kasar, protein kasar, dan gula yang berpotensi sebagai pupuk organik yang potensial (Purwaningsih 2011). Pemberian kompos kompos blotong merupakan dosis yang efektif dalam meningkatkan suplai hara dalam tanah yang seterusnya meningkatkan diameter batang tebu.

blotong ke dalam tanah akan berpengaruh pada sifat fisik, biologi, dan kimia tanah. Peran kompos blotong terhadap sifat fisik tanah antara lain merangsang granulasi, memperbaiki aerasi tanah, dan meningkatkan kemampuan menahan air. Hasil analisis kimia kompos blotong yang digunakan dalam penelitian dapat dilihat pada Tabel 5 berikut ini.

Tabel 5. Hasil analisis kimia kompos blotong

\begin{tabular}{lc}
\hline \multicolumn{1}{c}{ Komponen analisis } & Kandungan \\
\hline $\mathrm{pH}$ & 6.50 \\
$\mathrm{C}$-organik (\%) & 24.50 \\
$\mathrm{~N}$-total (\%) & 0.95 \\
$\mathrm{P}_{2} \mathrm{O} 5(\%)$ & 8.65 \\
$\mathrm{~K} 2 \mathrm{O}(\%)$ & 0.38 \\
$\mathrm{Ca}(\%)$ & 0.53 \\
$\mathrm{Mg}$ & 0.36 \\
$\mathrm{~S}(\%)$ & 0.20 \\
$\mathrm{Fe}(\mathrm{ppm})$ & 17087.46 \\
$\mathrm{Mn}$ & 142.53 \\
$\mathrm{Cu}$ & $55.78 ; 56.18$ \\
$\mathrm{Zn}$ & 300.36 \\
$\mathrm{Kadar}$ air (\%) & 14.48 \\
\hline Sumber : $\quad$ Dari sampel Pabrik Madukismo dianalisis di \\
$\quad$ Laboratorium Departemen Ilmu Tanah dan \\
$\quad$ Sumberdaya Lahan (IPB)
\end{tabular}

Peran bahan organik terhadap sifat biologi tanah adalah meningkatkan aktivitas mikroorganisme yang berperan pada fiksasi nitrogen dan transfer hara tertentu seperti N, P, K, dan S. Peran bahan organik terhadap sifat kimia tanah adalah meningkatkan kapasitas tukar kation (KTK) sehingga dapat mempengaruhi serapan hara oleh tanaman (Gaur, 1981). Dari hasil analisis di atas, nilai $\mathrm{pH}$ kompos blotong yang diperoleh sebesar 6.5. Kompos blotong yang baik untuk pertumbuhan tanaman tebu memiliki $\mathrm{pH}$ sekitar 5 sampai 8 (Deptan, 2005). Hal ini menunjukkan bahwa kompos blotong yang digunakan dalam penelitian ini tidak terlalu masam dan alkali sehingga dapat menstabilkan nilai $\mathrm{pH}$ lahan lingkungan karena tanah dengan $\mathrm{pH}$ rendah dapat menjadi faktor pembatas pertumbuhan tanaman tebu dan mempengaruhi proses penyerapan unsur hara oleh akar di bawah tanah. Unsur hara C, N, P, K, $\mathrm{Ca}, \mathrm{Mg}, \mathrm{S}, \mathrm{Fe}, \mathrm{Mn}, \mathrm{Cu}$, dan $\mathrm{Zn}$ dalam kompos blotong diharapkan dapat memperbaiki sifat fisika dan biologi tanah serta memberikan tambahan unsur 
hara ke dalam media tanah yang digunakan. Menurut Kirana (2008) pemberian kompos blotong tidak meningkatkan sifat kimia tanah tetapi meningkatkan unsur $\mathrm{N}$ dalam tanah daripada tanpa kompos blotong. Pemberian kompos blotong yang mengandung mikroba tanah akan membantu meningkatkan serapan hara ke dalam jaringan tebu. Kadar air dari kompos blotong yang digunakan sebesar $14.48 \%$ yang menunjukkan bahwa kompos blotong tersebut dapat menyuplai air pada lahan pertumbuhan tanaman tebu.

Tabel 6. Hasil analisis kimia tanah sebelum dilakukan pemupukan anorganik dengan kompos blotong

\begin{tabular}{llr}
\hline Metode analisis & Komponen & Tanah \\
\hline pH 1:1 & $\mathrm{H} 2 \mathrm{O}$ & 5.70 \\
& $\mathrm{KCl}$ & 4.47 \\
Walkey \& Black & C-organik (\%) & 3.00 \\
Kjehdal & N-total $(\%)$ & 0.60 \\
Bray 1 & $\mathrm{P}(\mathrm{ppm})$ & 19.80 \\
N NH4OAc pH 7.0 & $\mathrm{Ca}(\mathrm{me} / 100 \mathrm{~g})$ & 40.78 \\
& $\mathrm{Mg}(\mathrm{me} / 100 \mathrm{~g})$ & 12.08 \\
& $\mathrm{~K}(\mathrm{me} / 100 \mathrm{~g})$ & 0.51 \\
& $\mathrm{Na}(\mathrm{me} / 100 \mathrm{~g})$ & 5.54 \\
& $\mathrm{KTK}(\mathrm{me} / 100 \mathrm{~g})$ & 48.54 \\
& $\mathrm{~KB}(\%)$ & 100.00 \\
$N K C I$ & $\mathrm{Al}(\mathrm{me} / 100 \mathrm{~g})$ & $\mathrm{TR}$ \\
& $\mathrm{H}(\mathrm{me} / 100 \mathrm{~g})$ & 0.20 \\
\hline
\end{tabular}

Dalam penelitian ini, tebu telah ditanam di lahan kering yaitu lahan yang dalam keadaan alamiah lapisan atas dan bawah tubuh tanahnya sepanjang tahun atau hampir sepanjang tahun tidak jenuh air dan tidak tergenang (Kuntohartono et al., 1982). Kandungan liat dan besi yang tinggi dan rendahnya kandungan bahan organik dalam lahan kering dapat mengakibatkan tanah menjadi peka terhadap erosi dan pemadatan tanah. Kandungan besi yang tinggi mengakibatkan rendahnya kapasitas menyimpan air pada akhirnya menghambat penetrasi akar serta pertumbuhan akar. Selain itu, lahan kering bersifat masam, kesuburan tanah rendah, kandungan bahan organik dan aktivitas liat rendah, nilai kejenuhan basa dan KTK rendah serta kapasitas fiksasi fosfat tinggi (Sastrosumarjo 1995). Rendahnya unsur hara dalam lahan kering dapat diatasi dengan pemberian kompos blotong. Hasil analisis kimia tanah sebelum dilakukan pemupukan anorganik dengan kompos blotong dapat dilihat pada Tabel 6 .

Setelah tebu ditanam empat bulan dan tanah diberi pupuk anorganik dengan kompos blotong, tanah diambil dari setiap lima tempat perlakuan yang berbeda untuk dijadikan sampel analisis. Tanah diasumsi telah menyerap unsur unsur hara dari kompos blotong. Hasil analisis kimia tanah setelah pemupukan anorganik dengan kompos blotong disajikan pada Tabel 6. Menurut Wibowo et al. (2009), sifat kimia tanah yang cocok untuk tebu adalah $\mathrm{pH}$ 5.5-7.3, C-organik 0.32-1.7 \%, N-total 0.07-2.5\%, $\mathrm{P}_{2} \mathrm{O}_{5}$ 2.88-24.72 $\mathrm{mg} \mathrm{kg}{ }^{-1}, \mathrm{~K}_{2} \mathrm{O}$ 0.41-1.12 cmol kg-1, Na 0.77-2.5 cmol kg${ }^{-1}$, Ca $4.09-8.17 \mathrm{cmol} \mathrm{kg}^{-1}, \mathrm{Mg} 0.32-1.96$ cmol kg-1, KTK 16.79-30.58 $\mathrm{cmol} \mathrm{kg}^{-1}$, KB 25-50 $\%$. Dari hasil analisis kimia tanah didapatkan nilai $\mathrm{pH}$ tinggi pada $\mathrm{P} 1, \mathrm{P} 2, \mathrm{P} 3$, dan $\mathrm{P} 4$ yang menunjukkan pemberian kompos blotong mempengaruhi nilai $\mathrm{pH}$ tanah berbanding $\mathrm{P} 5$ yang tidak menggunakan kompos blotong sehingga nilai $\mathrm{pH}$ rendah. Pada $\mathrm{pH}$ di bawah 5.5 dapat menyebabkan perakaran tanaman tidak dapat menyerap air sedangkan apabila tebu ditanam pada tanah dengan $\mathrm{pH}$ di atas 7.0 tanaman akan sering kekurangan unsur fosfor (Sutardjo, 2002).

Tabel 7. Hasil analisis rutin kimia tanah setelah perlakuan pemupukan anorganik dengan kompos blotong

\begin{tabular}{|c|c|c|c|c|c|c|c|c|c|c|c|c|c|}
\hline \multirow{3}{*}{ perlakuan } & \multicolumn{13}{|c|}{ Metode analisis } \\
\hline & \multicolumn{2}{|c|}{$\mathrm{pH} 1: 1$} & \multirow{2}{*}{$\begin{array}{c}-\quad \mathrm{C}- \\
\text { organik } \\
(\%)\end{array}$} & \multirow{2}{*}{$\begin{array}{c}\mathrm{N}- \\
\text { total } \\
(\%)\end{array}$} & \multirow{2}{*}{$\mathrm{P}(\mathrm{ppm})$} & \multirow{2}{*}{$\begin{array}{c}\mathrm{Ca} \\
(\mathrm{me} / \\
100 \mathrm{~g})\end{array}$} & \multirow{2}{*}{$\begin{array}{c}\mathrm{Mg}(\mathrm{me} / \\
100 \mathrm{~g}\end{array}$} & \multirow{2}{*}{$\begin{array}{c}\mathrm{K}(\mathrm{me} / \\
100 \mathrm{~g})\end{array}$} & \multirow{2}{*}{$\begin{array}{c}\mathrm{Na} 9 \\
(\mathrm{me} / \\
100 \mathrm{~g})\end{array}$} & \multirow{2}{*}{$\begin{array}{c}\text { KTK } \\
(\mathrm{me} / \\
100 \mathrm{~g})\end{array}$} & \multirow{2}{*}{$\mathrm{KB}(\%)$} & \multirow{2}{*}{$\begin{array}{c}\mathrm{Al}(\mathrm{me} / \\
100 \mathrm{~g})\end{array}$} & \multirow{2}{*}{$\begin{array}{c}\mathrm{H}(\mathrm{me} / \\
100 \mathrm{~g})\end{array}$} \\
\hline & $\mathrm{H}_{2} \mathrm{O}$ & KCL & & & & & & & & & & & \\
\hline$\overline{\mathrm{P} 1}$ & 5.70 & 4.60 & 1.11 & 0.07 & 26.50 & 37.63 & 12.21 & 0.60 & 1.14 & 43.68 & 100.00 & TR & 0.20 \\
\hline P2 & 5.97 & 4.80 & 1.06 & 0.09 & 18.60 & 41.87 & 14.12 & 0.51 & 1.69 & 49.94 & 100.00 & TR & 0.20 \\
\hline P3 & 5.80 & 4.60 & 0.67 & 0.06 & 42.90 & 37.87 & 13.53 & 0.61 & 1.25 & 48.47 & 99.41 & 0.19 & 0.20 \\
\hline P4 & 5.93 & 4.53 & 0.82 & 0.10 & 42.21 & 40.11 & 11.54 & 0.62 & 1.26 & 46.36 & 100.00 & 0.07 & 0.20 \\
\hline P5 & 5.40 & 4.63 & 0.82 & 0.90 & 21.00 & 38.60 & 15.12 & 0.44 & 0.95 & 54.70 & 96.35 & 0.07 & 0.26 \\
\hline
\end{tabular}

Sumber : Sampel tanah dari lahan Desa Sengon dianalisis di Laboratorium Departemen Ilmu Tanah dan Sumberdaya Lahan (IPB) 
Kadar C-organik mengalami penurunan yang drastik pada semua kelompok perlakuan namun masih dalam kisaran yang cocok untuk tebu berbanding dengan kadar C-organik sebelum pemupukan anorganik dengan kompos blotong. Hal ini menunjukkan bahwa kompos blotong dapat menstabilkan kadar C-organik dalam tanah. Selain itu, kadar $\mathrm{N}$ menurun jika dibandingkan dengan hasil analisis tanah sebelum dilakukan pemupukan namun semuanya masih dalam kisaran yang cocok untuk tanaman tebu kecuali P3 yang sedikit lebih rendah. Hal ini diduga karena pupuk $\mathrm{N}$ dapat hilang melalui penguapan, terbawa aliran permukaan, pencucian, ataupun dimanfaatkan oleh mikroba tanah (Purnomo dan Suriadikarta, 2013). Unsur P pada semua perlakuan menunjukkan peningkatan dan lahan pada P3 paling tinggi berbanding yang lain yaitu 42.90 ppm. Unsur $\mathrm{P}$ berperan mengikat energi dari cahaya matahari menjadi energi metabolik (ATP). Selanjutnya, energi ATP ini digunakan dalam metabolisme pembentukan gula. Apabila terjadi defisiensi P maka berarti bahwa tanaman tebu akan kekurangan energi metabolisme dan pertumbuhan tanaman serta produksi gula akan berkurang. Selain itu, ketersediaan fosfor tergantung dengan $\mathrm{pH}$ tanah yang normal. Pada tanah masam, kelarutan kation - kation $\mathrm{Fe}, \mathrm{Al}, \mathrm{Mn}, \mathrm{Cu}, \mathrm{Zn}$ dominan, sedangkan pada tanah alkalin $\mathrm{Ca}$ dan $\mathrm{Mg}$ dominan. Ion fosfor sangat mudah bereaksi dengan kation - kation tersebut membentuk ikatan kompleks yang mengendap dan sukar tersedia. Unsur $\mathrm{S}$ yang diperoleh dari pupuk anorganik berperan sebagai katalisator dalam pembentukan unsur $\mathrm{P}$.

Tanah dengan kapasitas tukar kation (KTK) yang tinggi dapat memberikan hara yang baik (Kuntohartono, 1982). Hasil penelitian menunjukkan KTK untuk semua kelompok perlakuan meningkat. Hal ini mengindikasikan bahwa ketersedian hara sangat tinggi dalam memicu perkembangan tanaman tebu. Ketersedian hara ini mempengaruhi kejenuhan basa sehingga pada P3 terjadinya penurunan KB. Hal ini juga berkaitan dengan adanya zat aluminium yang bersifat toksik pada tanaman.

\section{KESIMPULAN}

Pengurangan dosis pemupukan anorganik $75 \%$ dengan kompos blotong $100 \%$ tidak berbeda nyata berbanding dosis pemupukan anorganik $100 \%$ dengan kompos blotong $100 \%$. Hasil taksasi maret tebu 6 bulan pada perlakuan pemupukan anorganik 75\% menghasilkan 95.88 ton sedangkan perlakuan pemupukan anorganik 100\% sebesar 92.64 ton. Pengurangan dosis pemupukan anorganik $75 \%$ dengan kompos blotong $100 \%$ dapat menggantikan dosis pemupukan anorganik $100 \%$ dengan kompos blotong $100 \%$ dalam meningkatkan produktivitas tanaman tebu lahan kering.

\section{DAFTAR PUSTAKA}

[BPS Klaten] Badan Pusat Statistik Klaten. 2014. Curah hujan di Klaten [Internet]. [diunduh pada 27 Juli 2015]. Tersedia pada : http://klatenkab.bps.go.id/Subjek/view/id/151 \#subjekViewTab3.

Clements, H.F. 1980. Sugarcane Crop Logging and Crop Control, Principles and Practice. London (UK): Pitman Publishing.

[Deptan RI] Departemen Pertanian Republik Indonesia. 2005. Prospek dan Arah Pengembangan Agribinis Tebu [internet]. [diunduh pada 8 Juli 2015]. Tersedia pada : http://www.deptan.go.id.

Dillweijn, C.V. 1952. The Botany of Sugarcane. New York (UK) : The Ronald Press Co.

Pawirosemadi, M. 2011. Dasar - Dasar Teknologi Budidaya Tebu dan Pengolahan Hasilnya. Malang (ID) : UM Press. [Disbun Jabar] Dinas Perkebunan Jawa Barat. 2013. Landasan Pola Budi daya Tebu [internet]. [diunduh pada 27 Juli 2015]. Tersedia pada : http://www.disbunjabar.co.id.

[Ditjenbun] Direktorat Jenderal Perkebunan. 2009. Statistik Indonesia Jakarta [internet]. [diunduh pada 22September 2014 2014]. Tersedia pada : http://ditjenbun.pertanian. go.id/setditjenbun/berita-172- dirjenbun-kebutuhan-gula-nasional-mencapai-5700-jutaton-tahun-2014.html.

[Ditjenbun] Direktorat Jenderal Perkebunan. 2015. Menuju penggunaan bahan organik untuk tanaman tebu. [internet]. [diunduh pada 28 Juli 2015]. Tersedia pada : http://ditjenbun.pertanian.go.id/tansim/berita241-menuju-penggunaan-bahan-organikuntuk-tanaman-tebu.html. 
Gaur, A.C. 1981. Improving Soil Fertilitiy through Organic Recycling : A Manual of Rural Composting. FAO. The United Nation, Rome.

Kirana, K. 2008. Penentuan Dosis Pemupukan Kompos Blotong pada Tebu Lahan Kering (Saccharum officinarum L.) Varietas PS 862 dan PS 864 [skripsi]. Bogor (ID): Institut Pertanian Bogor.

Kuntohartono , T. 1982. Pedoman Budidaya Tebu Lahan Kering. Yogyakarta (ID) : Lembaga Pendidikan Perkebunan.

Lahuddin. 1996. Pengaruh kompos blotong terhadap beberapa sifat fisik dan kandungan unsur hara tanah serta hasil tanaman jagung. Jurnal Penelitian Pertanian.1 : 13-18.
Mulyadi, M. 2000. Kajian pemberian blotong dan terak baja pada tanah Kandiodoxs pelaihari dalam upaya memperbaiki sifat kimia tanah, serapan $\mathrm{N}, \mathrm{Si}, \mathrm{P}$, dan $\mathrm{S}$ serta pertumbuhan tebu [tesis]. Bogor (ID): Institut Pertanian Bogor.

Purnomo, J., Suriadikarta, D.A. 2008. Respon tanaman tebu varietas Bulu lawang dan perubahan sifat kima tanah sebagai akibat dari pemberian pupuk N, P, K di PG Jati Tujuh Jawa Barat. Prosiding Seminar Nasional dan Dialog Sumberdaya Lahan Pertanian : $353-364$.

Purwaningsih, E. 2011. Pengaruh pemberian kompos blotong, legin, dan mikoriza terhadap serapan hara $\mathrm{N}$ dan $\mathrm{P}$ tanaman kacang tanah. Widya Warta. No 02. 